http://www.rusnauka.com/27_NII.../35257.doc

5. Kalendruz, I. Mixed fodder on the wheels [Electronic resource] / I. Kalendruz, B. Yasenetskiy - Access : http://propozitsiya.com

6. A trailer plant for preparing mixed fodders and fodder mixtures (RU 2492775) [Electronic resource] / Access : http://www.findpatent.ru/patent/249/2492775.html

7. Enterprises, buildings and constructions for keeping and grain processing: ДВN В.2.2-8-98. - [Valid since 199801-07]. - Kyiv : Dershbud of Ukraine, 1998. - 88 p. - Access : http://dbn.at.ua/load/normativy/dbn/1-1-0-391.

8. Rules of safe operation of electric plants: NPAOP 40.1-1.01-97. - [Valid since 1998-13-01]. - Kyiv : State labour protection of Ukraine. Ministry of Justice of Ukraine, 1998. - 23 p. - Access : http://zakon4.rada.gov.ua/laws/show/z0011-98.

9. Rules of safe operation of the customers electric plants (DNAOP 00-1.21-98) : NPAOP 40.1-1.21-98. - [Valid since 1998-10-02]. - Kyiv : State labour protection of Ukraine. Ministry of Justice of Ukraine, 1998. - 25 p. Access : http://zakon4.rada.gov.ua/laws/show/z0093-98

Надійшла 17.05.2016. До друку 24.05.2016

УДК 663.4.013.8:331.45

Irina Melnik, PhD, associate professor, Zinaida Saharova, senior lector,

Dasha Hnatovskaya, master

Odessa National Academy of Food Technologies, Odessa

\title{
LABOUR PROTECTION AND SAFETY IN THE BREWING INDUSTRY
}

\begin{abstract}
The article describes the quantification of the level of safety in the brewing industry, which allows determining the contribution of each employee to ensure healthy and safe working conditions. Factors have also been shown to affect the safety of each of the employees. Knowledge of the characteristics and limits of each of the factors makes it possible to secure workflow and solve potential problems early. Previously considered a comprehensive approach that allows full control of the security protecting the entire brewing industry.

Efficient and safe work is possible only if the working environment at the workplace to meet all the requirements of international standards in the field of occupational safety and health. Therefore, each category from a number of activities, which can significantly reduce the level of injury, and ending with the characteristics of each of the factors for drawing up a plan to ensure the maximum protection of the company's employees, was discussed. Chemical, physical, biological and psychophysical factors may exist alone or in combination with each other. It is therefore important to identify in advance all of them and to take all measures relating to ensure safe working conditions in each of the processes.

Separately considered optimal and allowable values of temperature, relative humidity and air velocity in the working area of industrial premises. The parameters were established for the purpose of continuous monitoring in order to ensure comfortable and safe work environment for each employee. In some cases it is necessary to consult with technicians to get the full picture of the possible threats posed by each type of equipment. Especially dangerous in terms of occupational safety and health in the brewing industry is a cooking workshop, where the air temperature in the working area is significantly increased, as well as the bottling plant (noisy).
\end{abstract}

Keywords: Safety, brewery, safe working conditions, safety, getting the wort.

\section{Introduction}

Assessment the level of occupational safety is one aspect of life safety, the most important task in the development, implementation and improvement of OSH management systems at the enterprises of the brewing industry and serves as a basis for effective functioning. Effective management of labor protection at the enterprise is possible only with quantitative assessment all levels of production. Necessary to distinguish the state of occupational safety and health of each individual worker (operator), the workplace and assessment with using the basic parameter - coefficient level of occupational safety and health, as well as evaluation of the work to ensure healthy and safe working conditions of officers, the level of labor protection led their divisions. Currently, there are two approaches to assessing the state of occupational safety and health in the workplace. The first is to determine the level of occupational safety factor structural unit as the arithmetic mean of the three factors and has significant shortcomings that hinder their widespread use in practice. The second approach to assessing the level of occupational safety and health on the site, in the workshop, and other departments, deprived of some of these disadvantages, is to evaluate the safety factor, which is determined by the heads of departments on a 
monthly basis. The proposed method for quantitative assessment contributes to improving the oversight, planning, labor protection, material incentives for workers, OSH management system, which ultimately reduces the incidence of occupational injuries and work.

The aims and objectives of the research.

The complexity of modern production requires an integrated approach to health and safety. In these circumstances, the company performs the following tasks:

- Training employees on labor protection;

- Safety of production equipment;

- Ensuring the safety of buildings and structures;

- Providing employees with personal protective equipment;

- Ensuring optimal regimes of work and rest;

- Ensuring safety of production processes;

- Normalization of working conditions and others.

World improvement of working conditions of people in any part of the production has a great social importance. Creating a safe technique and technology, comprehensive mechanization and automation of production, and on their basis - ensuring all areas of the enterprise environment that prevents industrial injuries, occupational diseases, and heavy physical labor - these are the main areas of occupational safety and health.

Occupational safety - system of preservation life and health of workers in the workplace, which includes legal, socio-economic, organizational and technical, sanitary and hygienic, medical and preventive, rehabilitative measures.

Safety - is the absence of unacceptable risk associated with the possibility of damage.

Safe working conditions - is the working conditions under which the impact on the working of harmful or hazardous production factors excluded, or their levels of exposure does not exceed the established norms.

Ensuring the safety of production facilities begins at the design stage and continues during the construction and commissioning by the use of reasonable standards and practices.

Under occupational safety is meant a set of measures of technical and organizational measures aimed at creating a safe working environment and preventing accidents at work [1].

\section{Materials and methods}

In the framework of labor protection at the enterprises systematically conducted activities that provide accident prevention and elimination of the possibility of accidents. These activities are generally reduced to the following:

- improve the design of existing equipment in order to protect workers from injuries;

- construction of new and improvement of existing construction safety equipment for machine tools, machines and heating installations, eliminating the possibility of injury;

- improving working conditions: to provide sufficient light, a good ventilation, suction of dust from handling places, the timely removal of waste products, maintaining the normal temperature in the shops, in the workplace and in the heat-radiating aggregates;

- eliminate the possibility of accidents during operation of the equipment, the gap grinding wheels, breaking rapidly rotating saws, acid splashing explosion of blood vessels and arteries, high pressure, flame emission or molten metals and salts from the heating device, the sudden inclusion of electric, electric shock, etc.;

- organized to familiarize all incoming work to the rules of conduct on the premises and the basic safety rules, systematic training and testing of knowledge working of the safety requirements;

- ensuring work safety instructions and work areas - posters, clearly showing dangerous areas in the workplace and measures to prevent accidents.

Healthy and safe working conditions is largely provided technical progress, improvement of technology and production technology (replacement of heavy physical work machines, the introduction of robots replacing human where it is dangerous to life and health, sealing processes in the chemical industry). But if this equipment and production technology in itself does not eliminate hazards, for their elimination shall apply the measures provided for in the rules of labor law and labor protection to prevent or neutralize the impact on workers of dangerous and harmful factors.

\section{Research results}

The essence of the science of maintaining health and safety in the environment is to identify and identification of hazardous and harmful factors; development of methods and human means of protection by reducing hazardous and harmful factors to acceptable levels; development of measures on liquidation of consequences of emergency situations. Exposure to hazards at work in certain circumstances leads to injury or other sudden sharp deterioration in health, and harmful - to disease and reduced efficiency. The main hazardous and harmful production factors specific to the nature of the brewery activities are:

- individuals;

- chemicals;

- biological;

- physiological.

In the brewing industry relate to physical factors:

- moving machinery, moving parts of equipment that may cause injury to workers;

- increased value of voltage in the electrical circuit, which may lead to electrical accident;

- increased levels of noise and vibration, which can lead to various violations of human health, including hearing loss;

- high or low temperature of the working area, which can lead to colds;

- increased dust and fumes in the air of the working area, which can lead to diseases of the respiratory system; $45^{\circ} \mathrm{C}$;

- a fever due to heating equipment surfaces above

- an electric shock, as well as the accumulation of static electricity; 
- chemically dangerous and harmful factors for the brewery include the impact on the human body of acids, alkalis, chlorine, sulfur, nitrogen compounds and other substances.

Infiltration of the body is possible via the airways, gastrointestinal tract and skin. Direct contact with such materials violates the normal course of physiological processes, reduces performance or even causes pathological changes in human organs and systems. The nature of emerging diseases and the degree of the toxic effects depend on the chemical structure of substances, each of which is a certain biological effect is inherent. Therefore, breweries should carefully conduct monitoring on the implementation of regulations on labor protection when working with corrosive substances. Workers must be provided with hermetic goggles, rubber gloves and boots, overalls made of thick acid-resistant fabrics, respirators for working with these substances.

The biological production factors include: pathogens and micro-organisms that can cause diseases of different systems of the human bodies.

Psychophysiological working conditions are characterized by the cargo value, lifted by hand, working posture and worker displacement in space, the pace at work, monotony, emotional tension, aesthetic and physical discomfort, shift modes. Psychophysiological working conditions are also defined working environment, relationships in the workplace. Therefore, it is important that the team favorable social and moral climate was created that is equally dependent on both the managers and the workers.

Industrial buildings, structures, equipment, processes, workplaces must meet the requirements of providing a healthy and safe working conditions. Such requirements are provided in the mandatory for the administration of uniform cross-industry and industry regulations on labor protection, sanitary rules and regulations that are developed and approved in accordance with the legislation [2].

In order to ensure healthy and safe working conditions, ambient air human environment must meet the established health and safety standards that meet the requirements. Climate parameters are developed in accordance with the requirements of SanPiN 9-80-RB98 "Hygienic requirements for the microclimate of industrial premises" and SDS 3.3.6.042-99. Optimal values of temperature, relative humidity and air velocity in the working area of industrial premises are presented in Table 1.1. Acceptable values of temperature, relative humidity and air velocity in the working area of industrial premises are shown in Table 1.2.

Table 1.1 - Optimum values of temperature, relative humidity and air velocity in the working area of industrial premises

\begin{tabular}{|c|c|c|c|c|}
\hline Period & Category gravity & Air temperature in the workplace, ${ }^{\circ} \mathrm{C}$ & Relative humidity, \% & Air speed, $\mathbf{m} / \mathbf{s}$ \\
\hline Cold & $\mathbf{P a}$ & 18-20 & 40-60 & 0,2 \\
\hline Warm & $\overline{P a}$ & 21-23 & $40-60$ & $\overline{\mathbf{0 , 3}}$ \\
\hline
\end{tabular}

Table 1.2 - Permissible values of temperature, relative humidity and air velocity in the working area of industrial premises

\begin{tabular}{|c|c|c|c|c|}
\hline Period & Category gravity & Air temperature in the workplace, ${ }^{\circ} \mathrm{C}$ & Relative humidity, \% & Air speed, m/s \\
\hline Cold & $\mathbf{P a}$ & $17-23$ & 75 & $0,2-0,3$ \\
\hline Warm & $\mathbf{P a}$ & 18-27 & 65 & $0,3-0,4$ \\
\hline
\end{tabular}


barriers. To reduce friction during crushing machines are constantly supplied with water. All employees of the crushing must wear earplugs to protect against noise. Important role played by the level of vibration control. Sampling is carried out with tanks only by using a special probe to avoid job injuries. Cereals sent directly to the brewhouse through pipelines. The mass is fed under pressure; any depressurization can result in adverse consequences.

Malt pellet, formed after the wort boiling, does not contain the harmful contaminants, but its shipment on individual drying and processing should be carried out in protective rubber gloves. Storage malt grains are carried out in a ventilated area with normalized moisture. Deviations from the norm could lead to the growth colonies of pathogens (biological impact factor), which can get into the air and is transmitted to humans through the respiratory tract. After preparing the pellet is sent to the production of animal feed products.

Sanitary activities in the areas must be aimed at protecting workers from grain dust, weeds and harmful impurities in the destruction of pathogenic microorganism's grain and malt. Elevated levels of grain dust can be the cause of occupational diseases (pneumoconiosis, conjunctivitis, skin diseases, etc.). For respiratory protection against dust workers engaged in cleaning and manual shoveling grain, should be provided with respirators or gauze bandages. The malting plants supply and exhaust ventilation must be arranged.

Sanitary requirements during the preparation of wort following: head department should be equipped with efficient ventilation and kept scrupulously clean; mash surface and seepage tanks and brew kettle should be smooth and accessible for cleaning.

Workers employed sanitization and disinfection of tanks for cooling the wort («plates"), should be provided with special rubber boots and coveralls, previously disinfected with $2 \%$ solution of bleach. Disinfection of tanks to ferment the wort is made after the mechanical treatment of the inner surface. Fermentation of wort is associated with the formation of a significant amount of carbon dioxide that accumulates in the lowest places of the premises, at the bottom of the tanks, which is dangerous to the health of workers producing sanitation. Therefore, you must be steamed or vats abundantly rinse with cold water. Low temperatures and high humidity air of many production facilities contribute to the emergence of colds among the workers of the brewing industry.

Timely and regular disinfection of premises and equipment allow maintaining the biological cleanliness in the workplace.

The premises of the crushing and cooking rooms shall be kept clean and have adequate ventilation. At least once a week, the ceilings and walls of the crushing department cleaned of dust. Equipment (crushers, silos) was purified from the flour dust and dirt daily. Bunkers for crushed malt must be dustproof.

Frequency of cleaning equipment is as follows: wort preparing units are washed with water before each new brewing mash; cold plates, settling tanks and hydrocyclone washed after their release from the sludge; closed cooling heat exchangers (tube and plate) washed with water on a daily basis; piping wort descent after each digestion was washed with water, and then they are steamed for 15-20 min.

Disinfection equipment for brewing and cooling the wort, as well as the communication is carried out at least 2 times per month. For disinfection using $2-4 \%$ of bleach solution [Ca (CO) 2], 0.5-3\% caustic soda solution $(\mathrm{NaOH}), 6.1 \%$ strength sodium carbonate solution (Sa2S03), antiformin, katapin and others. Before disinfection equipment is carefully cleaned mechanically from the remnants of wort, hop sediment.

Antiformin can be prepared in two ways. In the first method preparing three separate solutions: bleach $(5$ $\mathrm{kg}$ of lime are dissolved in 150 liters of water), sodium carbonate $(10 \mathrm{~kg}$ of soda dissolved in 20 liters of hot water at $\left.80-90{ }^{\circ} \mathrm{C}\right)$, caustic soda $(2.5 \mathrm{~kg}$ hydroxide sodium is dissolved in 12 liters of hot water). After preparation of solutions and mixing the first and second solutions are poured into a caustic solution, the mixture was well stirred and allowed to complete clarification of 7 days. The solution was decanted from the precipitate, diluted 15-20 times with water to give a working solution antiformin.

This solution was poured all piping wort and beer and held for at least 2 hours. All pipes were washed with cold water and steamed up until the output appears strong jet of steam. Then all lines and hoses again washed with cold water.

For disinfection technology and communications equipment can be used a simple method in which the filter tank is filled with hot strong caustic soda solution for 2-4 hours, and pumped his pump on all pipelines, as well as through the valves of the tank. The solution was then poured into a brewing kettle where soda ash is dissolved beforehand, was added to cold water to the desired volume and poured under continuous agitation bleach. The resulting solution antiformin can use for disinfection.

Sealed freezers treated once a decade hot solution of $1 \%$ caustic for 15 minutes, then washed with hot and then cold water. It is recommended to use CIP disinfecting refrigerators. Irrigation refrigerators 1 time per day and cleaned for 30 minutes covered with a thick solution of lime, clean brushes and washed with water. The resulting beer stone is removed periodically concentrated caustic soda solution or a mixture of yeast and sulfuric acid (100: 1).

Disinfection of equipment is carried out only in the goggles, rubber boots, apron and gloves.

After contact with alkali or acid on the skin should immediately rinse with cold water.

To protect the respiratory system from dust working here must be used gauze bandages on his nose and mouth.

Mash and boiling wort is carried out in units with steam heating. Heating steam pressure should not exceed $0.2 \mathrm{MPa}$.

In launching devices drive mixers tanks with agitators should be inscriptions of names of devices and their serial numbers.

All units of the brewing equipments must be equipped with exhaust pipes and the inside covered by stationary lights in a gated voltage performance is not higher than $12 \mathrm{~V}$. 
Tanks equipped with hot water and insulation for blocking water overflow.

Do not bend over the edge of the wort boiler. When boiling wort in the case of spilling it over the edge necessary to put in cold water pot, and turn on the mixer.

Centrifugal separators for wort and beer placed in a separate room in the shock absorbers, in accordance with the requirements of the installation instructions.

Separator rotor speed must strictly comply with the rating value and checked on the tachometer.

Separator drum assembly is carried out in strict accordance with digital stamps on the details. The separators must be fitted with the brakes. When the vibration, knocks, sharp change of rotor speed separator immediately stopped and to troubleshoot the job do not include. When disassembling the separator need to disconnect it from the mains, use only serviceable hoist; are not allowed to stand under the hoist. [1]
Efficient and safe work is possible only if the working environment at the workplace to meet all the requirements of international standards in the field of occupational safety and health.

\section{Conclusions}

Occupational safety is a system of preservation of life and health of workers in the workplace, has a wide range of areas in the social and labor sphere and requires the strengthening of public attention to the problems of improvement of working conditions, prevention of occupational injuries and occupational diseases. Technicians in the daily work solve the issues related to improving technology, improving the reliability of technical systems (equipment, machinery, etc.), safety of workers and of life, etc.

\title{
REFERENCES
}

1. K. Tkachuk, R. Sabarno (1982). Safety in industry. Kyiv, Technika, 231 p.

2. V. Gidetskiy, V. Jigerey, O. Melnikov (2000). Basics of labor protection. Lviv, Afisha, 348 p.

3. Scientific-practical commentary to the Law of Ukraine "On Labour Protection" (1996). Kyiv, Osnova, 528 p.

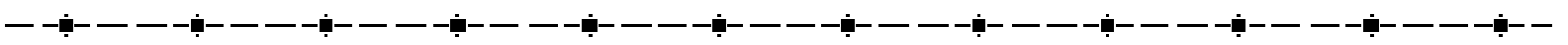

\section{І.В. МЕЛЬНИК, канд. техн. наук, доцент, 3.М. САХАРОВА, ст. викладач, Д.О. ГНАТОВСЬКА, магістранТ Одеська національна академія харчових технологій, м. Одеса ОХОРОНА ТА БЕЗПЕЧНІСТЬ ПРАЦ В ПИВОВАРНІЙ ГАЛУЗІ}

\begin{abstract}
Анотація
У статті розглянута кількісна оцінка рівня охорони праџі в пивоварному виробництві, щзо дозволяє визначити внесок кожного працівника в забезпечення здорових і безпечних умов прачі. Також наведені фактори, які впливають на безпеку роботи кожного зі співробітників. Знання особливостей і меж кожного з факторів дозволяє зробити робочий прочес безпечним і передчасно вирішити можливі проблеми, пов'язані з експлуатацією та обслуговуванням виробничого обладнання в ході технологічних прочесів. Попередньо розглядається комплексний підхід, який дозволяє повністю контролювати охорону безпеки всієї пивоварної галузі.

Ефективна і безпечна прачя можлива тільки в тому випадку, якщзо виробничі умови на робочому місці відповідають всім вимогам міжнародних стандартів в галузі охорони прачі. Тому була розглянута кожна категорія в контексті ряду заходів, які дозволяють значно знизити рівень травматизму, $i$ закінчуючи характеристикою кожного з факторів для складання плану по забезпеченню максимального захисту співробітників підприємства. Хімічні, фізичні, біологічні та психофізичні чинники можуть існувати як окремо, так $і$ в комплексі один з одним. Тому важливо заздалегідь розпізнати кожен з них і вжити всіх заходів, щуо стосуються забезпечення безпечних умов роботи на кожному з процесів.

Окремо були розглянуті оптимальні та допустимі величини температури, відносної вологості і швидкості руху повітря в робочій зоні виробничих приміщень. Дані параметри були встановлені з метою їх постійного контролю для того, щьб забезпечити комфортні та безпечні умови прачі для кожного зі співробітників. У деяких випадках необхідно консультуватися у технічних фахівців, щзоб отримати повну картину можливих загроз з боку кожного типу обладнання. Особливо небезпечними з точки зору охорони прачі в пивоварної галузі є цеех варіння, де температура повітря в робочій зоні значно підвищена, і цех розливу (високий рівень шуму).
\end{abstract}

Ключові слова: охорона прачі, солод, ячмінь, пивоварне виробництво, безпечні умови праці, безпеку, отримання сусла.

\section{ЛІТЕРАТУРА}

1. К. Ткачук, Р. Сабарно. Безопасность труда в промышленности. Киев, Техника, 1982. - 231 с.

2. В. Гидерский, В. Жигерей, О. Мельников. Основь охрань труда: Львов, Афиша, 2000. - 348 с.

3. Научно-практический комментарий к Закону Украины "Об охране труда". Киев: Основа, 1996. $-528 c$.

Надійшла 29.04.2016. До друку11.05.2016 